\title{
Ghrelin in Growth and Development
}

\author{
J.-P. Chanoine \\ Endocrinology and Diabetes Unit, British Columbia's Children's Hospital, University of British Columbia, \\ Vancouver, B.C., Canada
}

\section{Key Words}

Ghrelin - Growth hormone secretagogue receptor •

Fetal pancreas - Anorexia nervosa - Obesity .

Prader-Willi syndrome

\begin{abstract}
Exogenous administration of ghrelin increases caloric intake and stimulates growth hormone (GH) secretion, two effects that are mediated through binding of ghrelin to the GH secretagogue receptor (GHS-R). In addition, ghrelin is thought to inhibit adipogenesis by GHS-R-independent mechanisms. In adults, ghrelin is mainly produced by the stomach. In contrast, in the fetal and early postnatal period, ghrelin gene expression is abundant in the pancreas but not in the stomach. While knockout animal studies demonstrate that ghrelin is not required for perinatal development under normal nutritional conditions, the characteristics of ghrelin metabolism during fetal development suggest that ghrelin could contribute to the programming of mechanisms involved in energy balance, such as $\beta$-cell maturation, orexigenic pathways and adipogenesis. In humans, ghrelin concentrations progressively decrease during childhood and adolescence, as well as with advancing puberty. In adolescents, similar to adults, ghrelin concentrations are inversely related to body mass index and to circulating insulin. One
\end{abstract}

notable exception is the presence of elevated ghrelin concentrations in subjects with Prader-Willi syndrome, raising the possibility that ghrelin could be part of the etiology of excess food intake in this condition. These data raise a number of fascinating questions on the potential physiologic role of this hormone during growth and development.

Copyright $\odot 2005$ S. Karger AG, Basel

\section{Introduction}

Growth hormone secretagogues (GHS) are artificial compounds with potent growth hormone (GH)-secreting properties that were first developed in the 1970s [1]. The GH secretagogue receptor (GHS-R) to which these GHS bind is a $G$ protein-coupled receptor that was cloned in 1996 [2]. Ghrelin, the first natural ligand for the GHS-R, was isolated in 1999 [3].

Ghrelin is a 28-amino-acid peptide secreted primarily by the fundus of the stomach in adult humans [4] and animals [3]. It has the unique characteristic of having a hydroxyl group of one of its serine residues (Ser 3) acylated by $n$-octanoic acid. This acylation by $n$-octanoic acid is necessary for the binding of ghrelin to the GHS-R ([3], rev. in [5]).

\section{KARGER}

Fax +4161306 1234 E-Mail karger@karger.ch www.karger.com
(C) 2005 S. Karger AG, Basel 0301-0163/05/0633-0129\$22.00/0

Accessible online at:

www.karger.com/hre
Jean-Pierre Chanoine, $\mathrm{MD}, \mathrm{PhD}$

Endocrinology and Diabetes Unit, Room K4-212

British Columbia's Children's Hospital, 4480 Oak Street

Vancouver BC V6H 3V4 (Canada)

Tel. +1 604875 2624, Fax +1 604875 3231, E-Mail jchanoine@cw.bc.ca 
Fig. 1. Schematic diagram of the effect of ghrelin on growth hormone (GH) metabolism in adults. Ghrelin is secreted mainly by the stomach but also by the hypothalamus. Ghrelin regulates $\mathrm{GH}$ releasing hormone (GHRH) expression in the hypothalamus in vivo. It also directly stimulates $\mathrm{GH}$ release from the pituitary, at least in vitro. These actions are mediated through the GH secretagogue receptor (GHS-R).

Fig. 2. Schematic diagram of the effect of ghrelin on energy metabolism in adults. Ghrelin is secreted mainly by the stomach but also by the hypothalamus. Ghrelin stimulates appetite in the hypothalamus through stimulation of neuropeptide Y (NPY), a potent orexigenic agent, and of agouti-related protein (AgRP), a melanocortin receptor inverse agonist. These actions are mediated through the $\mathrm{GH}$ secretagogue receptor (GHS-R). Ghrelin is also thought to stimulate adipogenesis through GHS-R independent mechanisms. $\alpha$-MSH $=\alpha$-Melanocortin-stimulating hormone; $\mathrm{MC} 4-\mathrm{R}=$ melanocortin receptor; $\mathrm{POMC}=$ proopiomelanocortin.
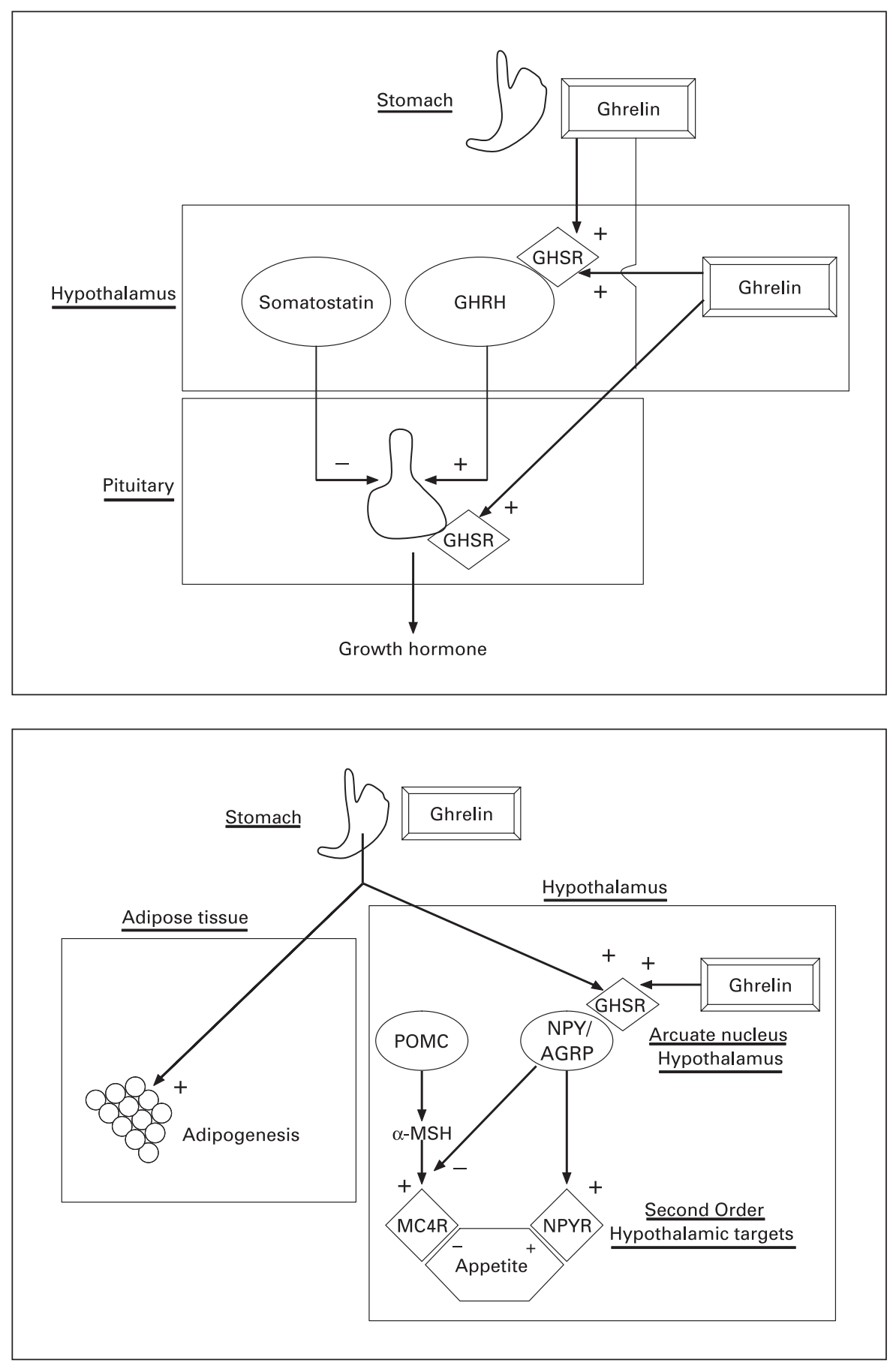

Ghrelin, like synthetic GHSs, stimulates GH secretion and has potent orexigenic effects. Both effects are mediated by the GHS-R [6]. Ghrelin stimulates GH secretion in the hypothalamus, an action that requires GH-releasing hormone (GHRH) (fig. 1) [7]. The effects of ghrelin on appetite are mediated mainly in the hypothalamus through stimulation of neuropeptide Y (NPY), a potent orexigenic agent, and of agouti-related protein (AgRP), a melanocortin receptor inverse agonist (fig. 2) [8]. However, neither stimulation of NPY or AgRP by ghrelin seems to be necessary for the regulation of energy balance [9]. In addition, ghrelin also promotes a positive energy 
balance through stimulation of adipogenesis independently from its effect on appetite. This effect may be mediated through GHS-R-independent pathways $[10,11]$.

The demonstration that ghrelin gene expression is present in the placenta [12] as well as in the fetal and/or neonatal pancreas [13-16], pituitary [17] and hypothalamus [18], raised the possibility that ghrelin may play a role in the maturation of the mechanisms implicated in energy balance. The goal of the present work is to review the animal and human data on ghrelin during development and to highlight the differences in ghrelin metabolism between the perinatal period and adulthood.

\section{Search Methods}

Articles were identified using the PubMed database (www.ncbi.nlm.nih.gov/pubmed). The key word used was ghrelin. All published or in press articles listed in the search until November 15, $2004(n=919)$ were screened for relevance to the topic of the review. Additional reports were identified from a review of references listed in the reports located through the PubMed search.

\section{Technical Issues}

Ghrelin results are reported as $\mathrm{pg} / \mathrm{ml}$ or $\mathrm{pmol} / \mathrm{l}$. Using the molecular weight of deacylated human ghrelin ([DesOctanoyl-Ser3], MW: 3,245) the conversion factor between SI and conventional units is: $\mathrm{pmol} / \mathrm{l}=\mathrm{pg} / \mathrm{ml} \times$ 0.296. The acylated form of ghrelin is responsible for the biological actions of ghrelin resulting from binding to and activation of the GHS-R and is therefore referred to as the 'active' form of ghrelin. It represents less than 10-20\% of total (acylated and deacylated) ghrelin immunoreactivity, which is measured by most commercial assays. Deacylated ghrelin immunoreactivity is relatively stable and is well preserved if collected in chilled EDTA-aprotinin tubes. In contrast, the acylated form of ghrelin is very unstable. As the enzymatic mechanisms regulating deacylation of ghrelin become better understood [19], more effective methods of preserving acylated ('active') ghrelin will become available [20,21]. The concentration of total ghrelin reported in the literature also varies with the assay used. Two widely used commercial assays (Linco, Saint Charles, Mo., USA and Phoenix, Belmont, Calif., USA) are known to yield greatly different absolute values. In agreement with Groschl et al. [22], we demonstrated [23] that part of this difference could be accounted for by different potencies in the ghrelin standards provided by the two companies. Thus, when critically evaluating the ghrelin literature, the reader needs to keep in mind that comparison of published total ghrelin concentrations is difficult and that it is usually assumed that the concentrations of total ghrelin accurately reflect those of acylated ghrelin. This latter assumption may be correct in human umbilical cord blood [24], although it remains to be proven under specific pathological situations.

\section{Lessons Learned from Ghrelin and Ghrelin Receptor Defects}

\section{Animal Knockout Models for Ghrelin or the Ghrelin Receptor Genes}

Exogenous administration of ghrelin markedly stimulates food intake and $\mathrm{GH}$ secretion in rodents. It was therefore tempting to hypothesize that complete ghrelin deficiency would impair growth and development. Two ghrelin $[25,26]$ and one ghrelin receptor knockout models [6] were developed to test these hypotheses.

In both ghrelin knockout models, the entire coding region of the gene was deleted, resulting in a complete absence of ghrelin in all tissues tested. Ghrelin-/- mice showed normal fertility and litter size. Overall, body weight and composition, fed and fasting glucose, insulin and leptin concentrations $[25,26]$ as well as fasting plasma GH concentrations [26] were similar in ghrelin-/and wild-type animals. In addition, daily food intake [25, 26], hypothalamic orexigenic (NPY, AgRP) and anorexigenic (proopiomelanocortin [POMC]) neuropeptide mRNAs [26] as well as food intake during refeeding following a $24 \mathrm{~h}$ fast were also unaffected by deletion of the ghrelin gene. However, a significant decrease in the respiratory quotient and a trend towards a decrease in fat mass - without changes in body weight - were reported in ghrelin-/- mice following 6 weeks on a high-fat diet [26]. These data raise the possibility that ghrelin could modulate the type of metabolic substrate (carbohydrate vs. fat) preferentially used to maintain energy balance, particularly in the presence of a high-fat diet and are consistent with the decrease in fat utilization observed in adult rats following exogenous administration of ghrelin [10].

Deletion of the ghrelin receptor gene causes a modest decrease in weight gain as well as a decrease in insulinlike growth factor-1 (IGF-1), suggesting that GHS-R plays a physiologic role in energy balance and $\mathrm{GH}$ regulation. A similar phenotype has also been reported by Shuto et al. [27] in transgenic rats where the synthesis of GHS-R 


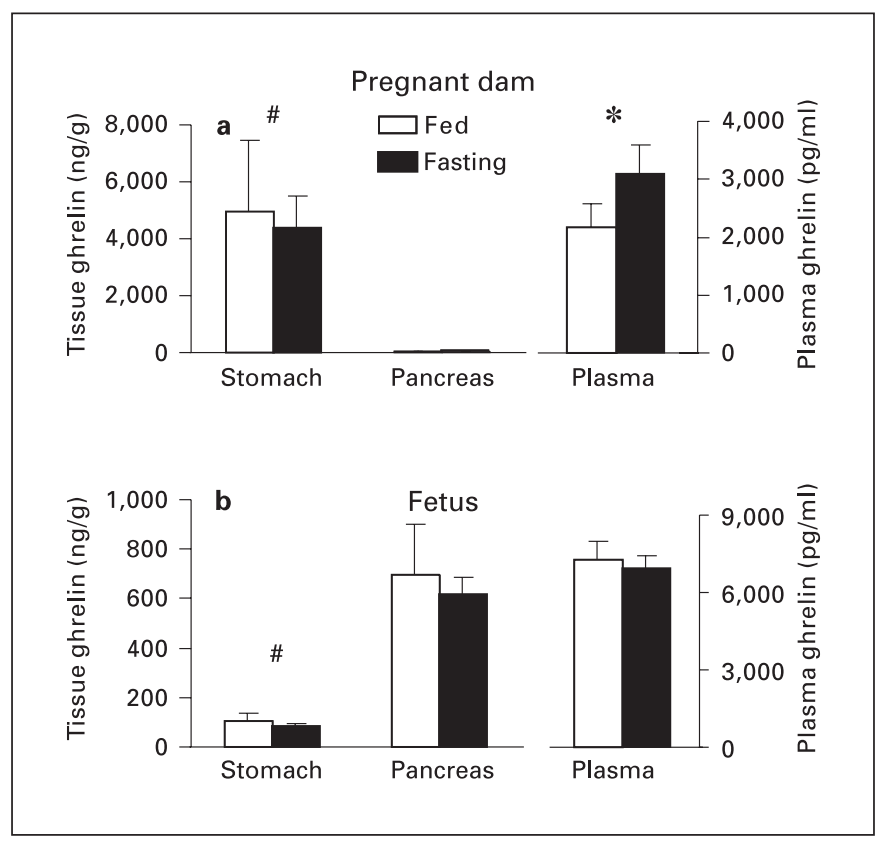

Fig. 3. Stomach, pancreas and plasma total ghrelin concentrations in fed and fasting pregnant dams (a) and their 20-day-old fetuses (b). In contrast to what was observed in the dam, tissue ghrelin concentrations were markedly higher in fetal pancreas compared to fetal stomach. Following $36 \mathrm{~h}$ fasting, plasma total ghrelin concentrations increased as expected in the dam $(+42 \%)$ but not in the fetus. $\mathrm{p}<0.0001$ by 2 -way ANOVA. Mean (SD); ${ }^{\#} \mathrm{p}<0.05 \mathrm{com}$ pared to pancreas; $* \mathrm{p}<0.05$ compared to plasma in fed animals. Modified from Chanoine et al. [13].

protein was attenuated through expression of an antisense GHS-R mRNA in the hypothalamus.

These results may seem disappointing compared to the clear phenotype of massive obesity observed for instance in the ob/ob mice, a strain lacking the anorexigenic peptide leptin [28]. However, it should be remembered that they are consistent with the absence of a major phenotype observed in knockout models of NPY, a potent orexigenic peptide stimulated by ghrelin injection and modulating its action in the hypothalamus [29].

\section{Ghrelin and Ghrelin Receptor Mutations in Humans}

Systematic studies of large cohorts of obese children and adolescents do not support the hypothesis that singlegene mutations of the ghrelin [30] or the GHS-R genes [31] are a common cause of obesity. A polymorphism of the ghrelin gene that causes substitution of a highly conserved leucine for a methionine (Leu72Met) has been associated with earlier onset of obesity [30], although this remains to be confirmed $[32,33]$. Interestingly, Pantel et al. [34] recently reported the presence of a mutation of the ghrelin receptor gene in a family where short stature is inherited in a dominant fashion. The missense mutation markedly decreased binding of ghrelin to the mutant receptor, suggesting that integrity of this pathway is required for normal growth.

Thus, the absence of ghrelin does not prevent normal fetal growth and development, at least in rodents. However, ghrelin may be required for metabolic actions that are not mediated through the GHS-R, such as adipogenesis. In addition, human and animal studies suggest that the presence of a normal GHS-R may be more important than ghrelin itself for the integrity of the GH-IGF-1 axis. In support of this hypothesis, it has recently been demonstrated that the GHS-R is constitutively activated and that it signals with $50 \%$ efficacy even in the absence of ghrelin [35]. Conditional or tissue-specific knockout models of ghrelin or GHS-R may be needed to understand the physiologic role of ghrelin.

\section{Animal Data}

\section{Different Anatomical Location of Ghrelin in the Pre- and Postnatal Periods}

Both acylated ('active') and deacylated ghrelin are present in fetal rat plasma on day 20 of gestation [13]. In contrast to active ghrelin, concentrations of total ghrelin are significantly higher in the fetus compared to the dam (fig. 3) [13]. Postnatally, ghrelin is present in the plasma at least by the second week of life, without clear age- or sex-related changes until weaning [36, 37].

Interestingly, tissue distribution of ghrelin greatly differs in the fetal and the postnatal periods. Ghrelin is present in the whole fetus as early as on day 12 of pregnancy [18]. Low levels of ghrelin gene expression are present in the fetal stomach by day 18 of gestation [13, 37, 38], a tissue traditionally regarded as a major source of circulating ghrelin in the adult $[3,36]$. Postnatally, stomach ghrelin gene expression increases markedly and reaches adult levels by $3-5$ weeks [18, 36-38]. In contrast, high levels of ghrelin gene expression are present in the fetal pancreas, suggesting that it may be a major source of circulating fetal ghrelin [13-15]. Ghrelin gene expression is 6-7 times higher in the fetal pancreas than in the fetal stomach on day 20 of gestation (fig. 3) [13] and decreases progressively during the first 2 weeks of life before reaching low levels of ghrelin gene expression in the adult pancreas [15]. Ghrelin in the fetal pancreas is produced by a novel endocrine cell type ( $\varepsilon$ cell) located in the pancre- 
atic islet $[14,15]$. In mice lacking $\mathrm{NKx}_{\mathrm{N}} 2.2$, a transcription factor that is essential for early differentiation of insulinproducing $\beta$ cells, $\beta$ cells are replaced by ghrelin-producing cells in the fetal islet, raising the possibility that ghrelin $(\varepsilon)$ - and insulin ( $\beta$ )-producing cells derive from a common endocrine precursor [14]. Ghrelin mRNA and protein have also been reported in the rat placenta near term $[12,18]$. Although placental concentrations of total immunoreactive ghrelin are low [13], placental tissue is abundant and could potentially contribute to the fetal pool of ghrelin.

\section{Ghrelin and Perinatal Energy Balance}

In keeping with a different anatomical origin, the nutritional regulation of ghrelin also differs between the preand postnatal periods. In adult rats (including pregnant dams [13]), fasting causes a marked increase in circulating total ghrelin concentrations (fig. 3) [39]. This physiologic fasting-associated rise in plasma total ghrelin is present by the end of the first postnatal week [38]. In contrast, in the fetus, plasma total ghrelin concentrations are unaffected by maternal fasting, despite a marked decrease in fetal plasma total glucose and insulin concentrations [13], a situation known to trigger an increase in circulating ghrelin in adult animals [39]. However, acylated ('active') ghrelin concentrations increase in the fetal pancreas with maternal fasting raising the possibility that ghrelin may mediate the effects of maternal nutrition on the developing pancreas [13].

Interestingly, daily administration of ghrelin directly to rat pups during the first 4 weeks of life does not affect postnatal weight gain [38], a finding that contrasts with the weight gain reported in adult mice following continuous infusion of ghrelin [10, 40]. A potential explanation could be the immaturity of the efferent projections in the neonatal hypothalamus [41]. In contrast, administration of ghrelin to the mother during the last week of gestation was associated with a 10-20\% increase in birth weight [38]. Similarly, exogenous administration of ghrelin in lactating dams increased milk secretion and the pups' weight gain [42]. These data raise the possibility that maternal ghrelin could affect energy balance in the fetus and the neonate through mobilization of maternal resources.

The demonstration that GHRP-6 (a synthetic GHS) and ghrelin both regulate the expression of the transcription factor Pit-1 raises the possibility that ghrelin is involved in the differentiation of the anterior pituitary and in the development of the GH-IGF-1 axis [43]. Postnatally, pituitary ghrelin mRNA decreases progressively from birth to adulthood [18]. A single injection of ghrelin causes a 2-3-fold increase in plasma $\mathrm{GH}$ concentrations by 1 week of age [38], a finding consistent with the demonstration of GHS-R mRNA in the pituitary [44] and the hypothalamus [45] early in life. In contrast, the physiologic role of endogenous ghrelin on neonatal GH secretion remains unclear. Immunization-induced decrease in GHRH sufficient to cause an $80 \%$ decrease in plasma GH concentrations did not affect hypothalamic or pituitary ghrelin mRNA. Similarly, ghrelin gene expression was not affected in mice deficient in liver IGF-1, a defect associated with an increase in GH secretion [18].

Thus, ghrelin is present in the fetus and its tissue distribution differs from the adult. The abundance of ghrelin in the fetal endocrine pancreas suggests that ghrelin may regulate $\beta$-cell development. In addition, while ghrelin is not required for the survival of the fetus, it could potentially contribute to the programming of central pathways in response to perinatal environmental signals such as nutrition [46]. Such early effects have been recently suggested for leptin [47].

\section{Human Data}

\section{Ghrelin in the Fetus and the Neonate}

Immunoreactive ghrelin is present in umbilical cord blood samples as early as by the 20th week of gestation [48] in concentrations that are of the same magnitude as those reported in adults. Umbilical cord total ghrelin concentrations are higher than in maternal blood $[49,50]$ and are not affected by gender [51,52] or ethnicity [51]. They are also higher in small for gestational age (SGA) compared to appropriate for gestational age (AGA) neonates [48, 52-54] (fig. 4). A modest positive correlation between gestational age and ghrelin concentrations has been reported at least in AGA neonates [50, 52]. The interpretation of a negative correlation between birth weight and ghrelin observed by several authors, including ourselves, is made difficult by the inclusion in the published series of infants with two potential confounding variables, SGA and prematurity [48, 52-54].

The source of fetal ghrelin remains unclear. Human postmortem studies have shown that ghrelin is abundant in the fetal (but not the adult) thyroid [55], lung [56] and pancreas but less so in the fetal stomach, suggesting that, like in rodents, tissues other than the stomach contribute to the pool of circulating ghrelin in the fetus [16]. Ghrelin is not detected in term human placenta [12] and ghrelin concentrations are similar [48] or only modestly higher [53] in the umbilical vein compared to the umbilical ar- 


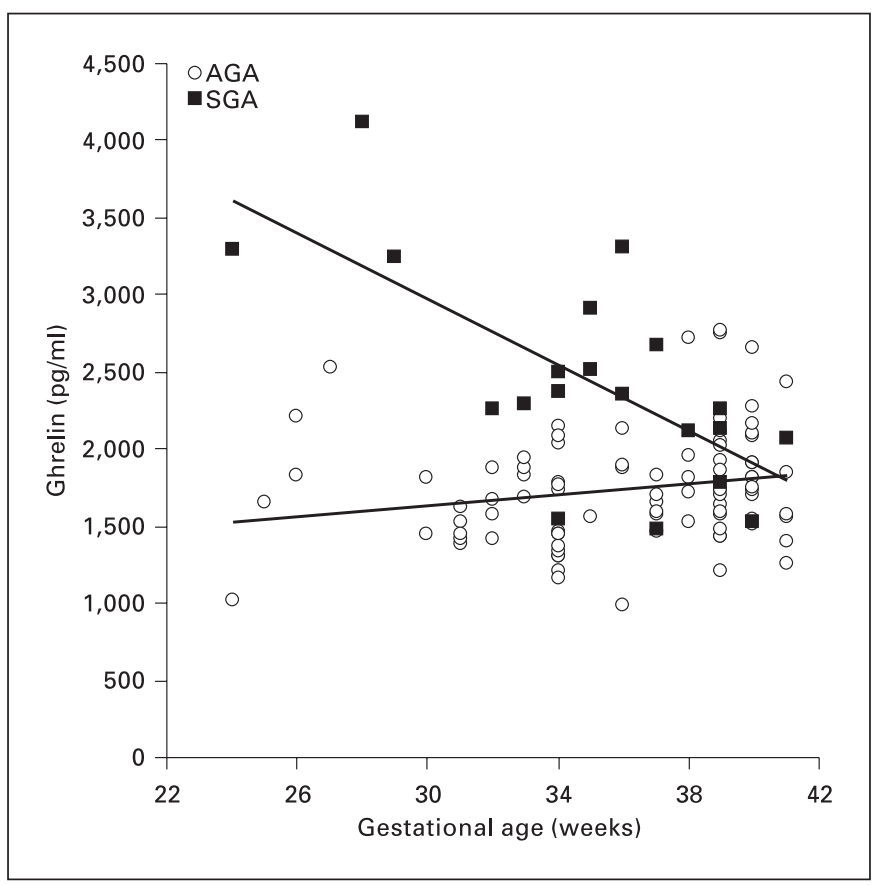

Fig. 4. Relationship between cord total ghrelin concentrations and gestational age in small for gestational age (SGA, $n=20, r=-0.68$, $\mathrm{p}=0.001)$ and appropriate or large for gestational age (AGA/LGA, $\mathrm{n}=103, \mathrm{r}=+0.22, \mathrm{p}=0.025)$. Mean $(\mathrm{SD})$ ghrelin concentrations were $43 \%$ higher in SGA $(1,737[378] \mathrm{pg} / \mathrm{ml})$ compared to AGA neonates $(1,218[674] \mathrm{pg} / \mathrm{ml})(\mathrm{p}<0.01)$ [52].

tery. Taken together, these data do not support the existence of a major placental contribution to fetal circulating ghrelin.

The role of ghrelin on weight gain and GH secretion during the perinatal period remains unclear. Ghrelin could potentially contribute to feeding initiation and positive energy balance. In support of this hypothesis, James et al. [57] found a modest association between lower cord blood ghrelin concentrations and slower weight gain for the first 12 postnatal weeks and Iniguez et al. [58] reported a greater drop in plasma ghrelin concentrations following IV glucose load in SGA infants with a slow weight gain between 0 and 1 years.

Ghrelin could also conceptually contribute to the high $\mathrm{GH}$ concentrations observed in cord blood. The in vitro demonstration of GHS-R mRNA and of an increase in GH secretion in response to GHRP-6 in the human fetal pituitary supports this hypothesis [59]. However, most studies failed to observe any significant correlation between umbilical cord ghrelin and GH concentrations [51, 53].

\section{Ghrelin in Children and Adolescents}

Circulating ghrelin concentrations progressively increase during the first 2 years of life [60] before decreasing during late childhood and adolescence [61], without gender-specific differences $[62,63]$. Ghrelin concentrations also decrease during puberty with advancing Tanner staging and are $30-50 \%$ lower in postpubertal compared to prepubertal subjects $[60,61]$. Although gonadal steroids may seem an obvious candidate for this puberty-associated decrease, the absence of a gender difference in ghrelin concentrations does not support this hypothesis.

Ghrelin and Energy Balance

In adults, ghrelin concentrations increase prior to the 3 main meals and decrease 30-90 min following the meal $[64,65]$. A temporal relationship between changes in ghrelin concentrations and hunger sensation has also been reported, raising the possibility that ghrelin may play a physiologic role in meal initiation [66]. The ontogenesis of the acute ghrelin response to caloric intake in humans is however unclear. It is present in adolescents (fig. 5) [67] and the recent report that this response may be absent in prepubertal subjects [68] suggests that it could develop progressively during childhood.

In adults, ghrelin administration induces hyperglycemia and decreases plasma insulin concentrations [69]. Conversely, hyperglycemia [70] and insulin (in the absence of hypoglycemia) [71] decrease plasma ghrelin. Similarly, a negative correlation between ghrelin and insulin concentrations has been reported in children and adolescents [62, 67, 72, 73]. A decrease in circulating ghrelin concentrations has also been observed in pediatric patients with newly diagnosed type 1 diabetes prior to initiation of insulin treatment and could be secondary to hyperglycemia [74]. Taken together, these data suggest that ghrelin is closely associated with glucose metabolism in adults as well as in children and adolescents.

Similar to adults $[4,75]$, ghrelin concentrations are increased in anorexic $[67,76]$ and decreased in obese adolescents $[62,67,77]$ and there is a negative correlation between ghrelin concentrations and body mass index [61, 62]. The decrease in circulating ghrelin in response to a mixed meal [67] (fig. 5) or to a glucose load [76, 77] is preserved in anorexic and obese adolescents. Renutrition in anorexic adolescents or weight loss in obese adolescents is associated with a normalization of fasting ghrelin concentrations [73]. In a prospective study performed in Pima Indian children, Bunt et al. [62] showed that ghrelin was not an independent predictor of future weight gain. 


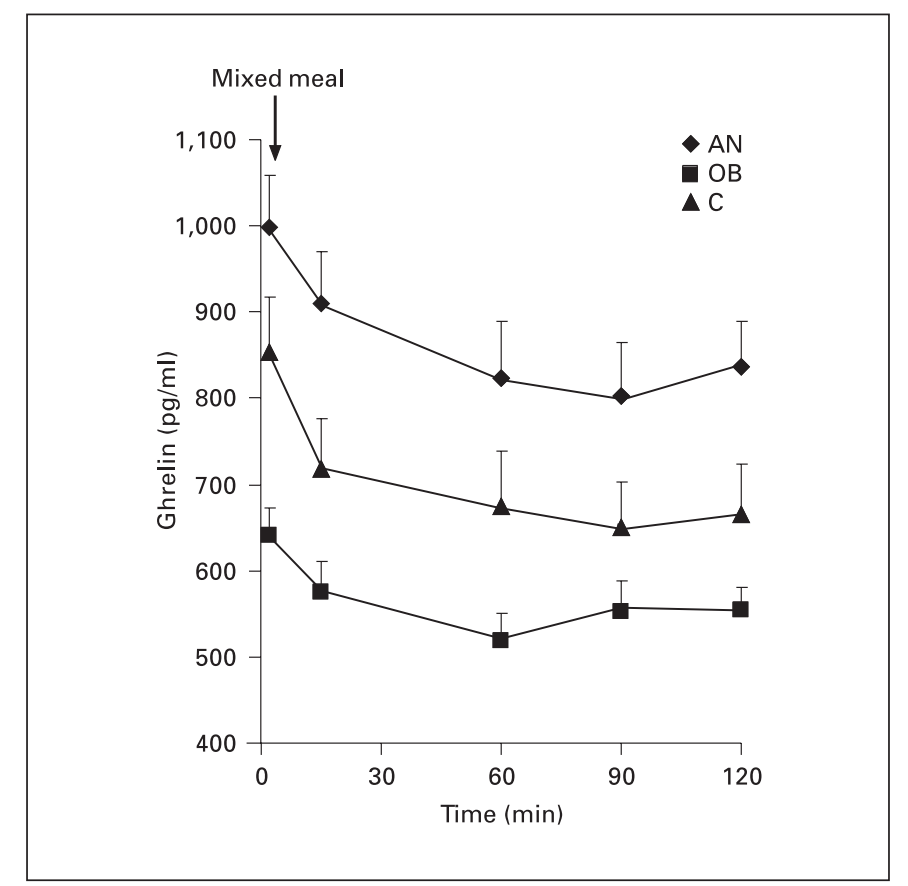

Fig. 5. Mean (SE) plasma total ghrelin concentrations in anorexic (AN) and obese (OB) adolescent girls compared to control subjects (C) during 120 min following a liquid mixed meal (mean age: 15.2 years). Ghrelin concentrations during the test were significantly higher in AN and lower in OB subjects compared to $\mathrm{C}$ adolescents ( $p=0.001$ by ANOVA, $p<0.05$ for pairwise comparisons by LSD). Mean (SD) percent decrease in ghrelin concentrations following the mixed meal was $25(8) \%(\mathrm{p}<0.01)$ and was similar in all 3 groups. However, the absolute mean [SD] decrease in ghrelin concentrations was lower in $\mathrm{OB}$ subjects (138 [49] $\mathrm{pg} / \mathrm{ml})$ compared to C $(236[78] \mathrm{pg} / \mathrm{ml})$ and AN subjects $(238[88] \mathrm{pg} / \mathrm{ml})(\mathrm{p}=0.007$ by ANOVA). Modified from Stock et al. [67].

\section{Ghrelin and GH Physiology}

Similar to adults, administration of a synthetic GHS in children without GH deficiency, or to children with GH deficiency but with intact pituitary function, causes a marked increase in plasma GH concentrations [78-80], suggesting that administration of the natural peptide ghrelin would also stimulate $\mathrm{GH}$ secretion in young subjects. Whether endogenous ghrelin is involved in the physiology of $\mathrm{GH}$ in children and adolescents remains to be demonstrated. Ghizzoni et al. [63] observed higher ghrelin and lower GH nocturnal concentrations in short children with neurosecretory dysfunction compared to short, non-GH-deficient children, suggesting that ghrelin may not be driving nighttime $\mathrm{GH}$ secretion. In a group of boys with constitutional delay of puberty, testosterone administration caused the expected increase in GH con- centrations but did not affect the 24-hour ghrelin profile, suggesting that the testosterone-induced GH secretion was not caused by ghrelin [81]. Finally, we recently observed a decrease in ghrelin concentrations following glucagon administration in a group of non-GH-deficient short children, suggesting that ghrelin does not mediate the glucagon-induced GH secretion [23].

Ghrelin and Prader-Willi Syndrome

Prader-Willi syndrome (PWS) is a genetic disorder characterized by poor weight gain in the early postnatal period, followed by excessive weight gain by age $1-3$ years. More than one third of patients with PWS weigh more than $200 \%$ of their ideal body weight $[82,83]$. Obesity is thought to result mainly from hyperphagia, decreased perception of satiety and obsessive and compulsive behaviors that are primarily food related [84, 85]. Patients also present with short stature, possibly due to GH deficiency of hypothalamic origin [86, 87].

In contrast to the low ghrelin concentrations observed in obese subjects without PWS, ghrelin concentrations are markedly elevated in obese children and adolescents with PWS subjects from birth [88-90]. The physiologic decrease in circulating ghrelin following a test meal is preserved $[91,92]$. The mechanism underlying these elevated ghrelin concentrations is unclear and working hypotheses include abnormal ghrelin regulation by proteins normally encoded by chromosome 15 [91], known to be abnormal in PWS or a primary hypothalamic defect [88]. Nevertheless, this unique observation raised the possibility that ghrelin might play a role in the hyperphagia and weight gain in these patients. Short-term infusion of octreotide, a somatostatin analogue, caused a marked decrease in circulating ghrelin in both young [91] and adult [93] subjects with PWS, but this was not associated with a decrease in appetite, at least in adult subjects [93]. Whether a prolonged decrease in ghrelin concentrations will be helpful in managing weight excess in these patients remains to be demonstrated. GH therapy for 1 year does not affect fasting ghrelin concentrations in patients with PWS $[88,94]$.

Thus, ghrelin is present in the perinatal period in humans where its role remains poorly understood. In adolescents, similar to adults, plasma ghrelin concentrations are decreased and increased in the presence of a positive and a negative energy balance, respectively. Whether these changes represent an adaptive response aiming at optimizing fat utilization as suggested in animal studies $[10,26]$ or whether they reflect an altered set-point for ghelin at the hypothalamic level is presently unknown. 


\section{Conclusions}

Ghrelin is present in the fetus and its tissue distribution differs from the adult. It binds to the GHS-R as early as during the fetal period. Although knockout animal studies suggest that ghrelin is not required for fetal and early postnatal growth and development under normal nutritional conditions, we speculate that ghrelin could contribute to the programming of the mechanisms involved in energy balance, such as $\beta$-cell development, orexigenic pathways and adipogenesis. Less than 5 years after the discovery of ghrelin, we are starting to under- stand some of the unique aspects of this hormone in the perinatal period. The characteristics of ghrelin metabolism outlined in this work raise a number of fascinating questions on the potential physiologic role of this hormone during growth and development.

\section{Acknowledgment}

This work was supported in part by grant \#1637 of the Canadian Diabetes Association.

\section{References}

1 Bowers CY: Unnatural growth hormone-releasing peptide begets natural ghrelin. J Clin Endocrinol Metab 2001;86:1464-1469.

$\checkmark 2$ Howard AD, Feighner SD, Cully DF, et al: A receptor in pituitary and hypothalamus that functions in growth hormone release. Science 1996;273:974-977.

3 Kojima M, Hosoda H, Date Y, Nakazato M, Matsuo H, Kangawa K: Ghrelin is a growthhormone-releasing acylated peptide from stomach. Nature. 1999;402:656-660.

$\checkmark 4$ Ariyasu H, Takaya K, Tagami T, Ogawa Y, Hosoda K, Akamizu T, Suda M, Koh T, Natsui K, Toyooka S, Shirakami G, Usui T, Shimatsu A, Doi K, Hosoda H, Kojima M, Kangawa K, Nakao K: Stomach is a major source of circulating ghrelin, and feeding state determines plasma ghrelin-like immunoreactivity levels in humans. J Clin Endocrinol Metab 2001;86: 4753-4758.

5 van der Lely AJ, Tschop M, Heiman ML, Ghigo E: Biological, physiological, pathophysiological, and pharmacological aspects of ghrelin. Endocr Rev 2004;25:426-457.

-6 Sun Y, Wang P, Zheng H, Smith RG: Ghrelin stimulation of growth hormone release and appetite is mediated through the growth hormone secretagogue receptor. Proc Natl Acad Sci USA 2004; 101:4679-4684.

7 Tannenbaum GS, Epelbaum J, Bowers CY: Interrelationship between the novel peptide ghrelin and somatostatin/growth hormone-releasing hormone in regulation of pulsatile growth hormone secretion. Endocrinology 2003; 144: 967-974.

8 Chen HY, Trumbauer ME, Chen AS, Weingarth DT, Adams JR, Frazier EG, Shen Z, Marsh DJ, Feighner SD, Guan XM, Ye Z, Nargund RP, Smith RG, Van der Ploeg LH, Howard AD, MacNeil DJ, Qian S: Orexigenic action of peripheral ghrelin is mediated by neuropeptide $Y$ and agouti-related protein. Endocrinology 2004;145:2607-2612.
-9 Qian S, Chen H, Weingarth D, Trumbauer ME, Novi DE, Guan X, Yu H, Shen Z, Feng Y, Frazier E, Chen A, Camacho RE, Shearman LP, Gopal-Truter S, MacNeil DJ, Van der Ploeg LH, Marsh DJ: Neither agouti-related protein nor neuropeptide $\mathrm{Y}$ is critically required for the regulation of energy homeostasis in mice. Mol Cell Biol 2002;22:5027-5035.

$>10$ Tschop M, Smiley DL, Heiman ML: Ghrelin induces adiposity in rodents. Nature 2000;407: 908-913.

11 Thompson NM, Gill DA, Davies R, Loveridge N, Houston PA, Robinson IC, Wells T: Ghrelin and des-octanoyl ghrelin promote adipogenesis directly in vivo by a mechanism independent of the type 1a growth hormone secretagogue receptor. Endocrinology 2004; 145:234-242.

12 Gualillo O, Caminos J, Blanco M, Garcia-Caballero T, Kojima M, Kangawa K, Dieguez C, Casanueva F: Ghrelin, a novel placental-derived hormone. Endocrinology 2001;142:788794.

13 Chanoine JP, Wong AC: Ghrelin gene expression is markedly higher in fetal pancreas compared with fetal stomach: Effect of maternal fasting. Endocrinology 2004; 145:3813-3820.

14 Prado CL, Pugh-Bernard AE, Elghazi L, SosaPineda B, Sussel L: Ghrelin cells replace insulin-producing beta cells in two mouse models of pancreas development. Proc Natl Acad Sci USA 2004; 101:2924-2929.

15 Wierup N, Yang S, McEvilly RJ, Mulder H Sundler F: Ghrelin is expressed in a novel endocrine cell type in developing rat islets and inhibits insulin secretion from INS-1 $(832 / 13)$ cells. J Histochem Cytochem 2004;52:301310.

16 Wierup N, Svensson H, Mulder H, Sundler F: The ghrelin cell: A novel developmentally regulated islet cell in the human pancreas. Regul Pept 2002;107:63-69.
17 Kamegai J, Tamura H, Shimizu T, Ishii S, Sugihara $\mathrm{H}$, Oikawa $\mathrm{S}$ : Regulation of the ghrelin gene: Growth hormone-releasing hormone upregulates ghrelin mRNA in the pituitary. Endocrinology 2001;142:4154-4157.

18 Torsello A, Scibona B, Leo G, Bresciani E, Avallone R, Bulgarelli I, Luoni M, Zoli M, Rindi G, Cocchi D, Locatelli V: Ontogeny and tissue-specific regulation of ghrelin mRNA expression suggest that ghrelin is primarily involved in the control of extraendocrine functions in the rat. Neuroendocrinology 2003;77: 91-99.

19 De Vriese C, Gregoire F, Lema-Kisoka R, Waelbroeck M, Robberecht P, Delporte C: Ghrelin degradation by serum and tissue homogenates: Identification of the cleavage sites. Endocrinology 2004;145:4997-5005.

20 Groschl M, Wagner R, Dotsch J, Rascher W, Rauh M: Preanalytical influences on the measurement of ghrelin. Clin Chem 2002;48: 1114-1116.

21 Hosoda H, Doi K, Nagaya N, Okumura H, Nakagawa E, Enomoto M, Ono F, Kangawa K: Optimum collection and storage conditions for ghrelin measurements: Octanoyl modification of ghrelin is rapidly hydrolyzed to desacyl ghrelin in blood samples. Clin Chem 2004;50: 1077-1080.

22 Groschl M, Uhr M, Kraus T: Evaluation of the comparability of commercial ghrelin assays. Clin Chem 2004;50:457-458.

23 Hirsh D, Heinrichs C, Leenders B, Wong ACK, Cummings DE, Chanoine JP: Ghrelin is suppressed by glucagon and does not mediate glucagon-related growth hormone release. Horm Res 2005;63:111-118.

$>24$ Kitamura S, Yokota I, Hosoda H, Kotani Y, Matsuda J, Naito E, Ito M, Kangawa K, Kuroda Y: N-octanoylated ghrelin levels in cord and neonatal blood. J Clin Endocrinol Metab 2004;89:4768 (letter).

-25 Sun Y, Ahmed S, Smith RG: Deletion of ghrelin impairs neither growth nor appetite. Mol Cell Biol 2003;23:7973-7981. 
-26 Wortley KE, Anderson K, Garcia K, Murray J, Malinova L, Liu R, Moncrieffe M, Thabet K, Cox H, Yancopoulos GD, Wiegand SJ, Sleeman MW: Deletion of ghrelin reveals no effect on food intake, but a primary role in energy balance. Obes Res 2004;12:170.

-27 Shuto Y, Shibasaki T, Otagiri A, Kuriyama H, Ohata H, Tamura H, Kamegai J, Sugihara H, Oikawa S, Wakabayashi I: Hypothalamic growth hormone secretagogue receptor regulates growth hormone secretion, feeding, and adiposity. J Clin Invest 2002;109:1429-1436.

28 Zhang Y, Proenca R, Maffei M, Barone M, Leopold L, Friedman JM: Positional cloning of the mouse obese gene and its human homologue. Nature 1994;372:425-432.

29 Herzog H: Neuropeptide Y and energy homeostasis: Insights from Y receptor knockout models. Eur J Pharmacol 2003;480:21-29.

-30 Miraglia del Giudice E, Santoro N, Cirillo G, Raimondo P, Grandone A, D'Aniello A, Di Nardo M, Perrone L: Molecular screening of the ghrelin gene in Italian obese children: The Leu72Met variant is associated with an earlier onset of obesity. Int J Obes Relat Metab Disord 2004;28:447-450.

- 31 Wang HJ, Geller F, Dempfle A, Schauble N, Friedel S, Lichtner P, Fontenla-Horro F, Wudy S, Hagemann S, Gortner L, Huse K, Remschmidt H, Bettecken T, Meitinger T, Schafer H, Hebebrand J, Hinney A: Ghrelin receptor gene: Identification of several sequence variants in extremely obese children and adolescents, healthy normal-weight and underweight students, and children with short normal stature. J Clin Endocrinol Metab 2004;89:157162.

- 32 Hinney A, Hoch A, Geller F, Schafer H, Siegfried W, Goldschmidt H, Remschmidt H, Hebebrand J: Ghrelin gene: Identification of missense variants and a frameshift mutation in extremely obese children and adolescents and healthy normal weight students. J Clin Endocrinol Metab 2002;87:2716.

- 33 Vivenza D, Rapa A, Castellino N, Bellone S, Petri A, Vacca G, Aimaretti G, Broglio F, Bona G: Ghrelin gene polymorphisms and ghrelin, insulin, IGF-I, leptin and anthropometric data in children and adolescents. Eur J Endocrinol 2004;151:127-133.

34 Pantel J, Cabrol S, Nivot S, Hilal L, Legendre M, Hajaji Y, Morisset S, de Kerdanet M, Kadiri A, Epelbaum J, le Bouc Y, Amselem S: Familial short stature associated with a mutation in the growth hormone secretagogue receptor (GHSR). Endocrine Society Meeting, New Orleans, 2004, p 84 (OR 10-86).

- 35 Holst B, Schwartz TW: Constitutive ghrelin receptor activity as a signaling set-point in appetite regulation. Trends Pharmacol Sci 2004; 25:113-117.

- 36 Lee HM, Wang G, Englander EW, Kojima M, Greeley GH Jr: Ghrelin, a new gastrointestinal endocrine peptide that stimulates insulin secretion: Enteric distribution, ontogeny, influence of endocrine, and dietary manipulations. Endocrinology 2002;143:185-190.
37 Liu YL, Yakar S, Otero-Corchon V, Low MJ, Liu JL: Ghrelin gene expression is age-dependent and influenced by gender and the level of circulating IGF-I. Mol Cell Endocrinol 2002; 189:97-103.

- 38 Hayashida T, Nakahara K, Mondal MS, Date Y, Nakazato M, Kojima M, Kangawa K, Murakami N: Ghrelin in neonatal rats: Distribution in stomach and its possible role. J Endocrinol 2002;173:239-245.

39 Toshinai K, Mondal MS, Nakazato M, Date Y, Murakami N, Kojima M, Kangawa K, Matsukura S: Upregulation of Ghrelin expression in the stomach upon fasting, insulin-induced hypoglycemia, and leptin administration. Biochem Biophys Res Commun 2001;281:12201225.

40 Wren AM, Small CJ, Abbott CR, Dhillo WS, Seal LJ, Cohen MA, Batterham RL, Taheri S, Stanley SA, Ghatei MA, Bloom SR: Ghrelin causes hyperphagia and obesity in rats. Diabetes 2001;50:2540-2547.

41 Grove KL, Smith MS: Ontogeny of the hypothalamic neuropeptide Y system. Physiol Behav 2003;79:47-63.

-42 Nakahara K, Hayashida T, Nakazato M, Kojima M, Hosoda H, Kangawa K, Murakami N: Effect of chronic treatments with ghrelin on milk secretion in lactating rats. Biochem Biophys Res Commun 2003;303:751-755.

43 Garcia A, Alvarez CV, Smith RG, Dieguez C: Regulation of Pit-1 expression by ghrelin and GHRP-6 through the GH secretagogue receptor. Mol Endocrinol 2001;15:1484-1495.

44 Kamegai J, Wakabayashi I, Kineman RD, Frohman LA: Growth hormone-releasing hormone receptor (GHRH-R) and growth hormone secretagogue receptor (GHS-R) mRNA levels during postnatal development in male and female rats. J Neuroendocrinol 1999;11: 299-306.

45 Katayama M, Nogami H, Nishiyama J, Kawase T, Kawamura K: Developmentally and regionally regulated expression of growth hormone secretagogue receptor mRNA in rat brain and pituitary gland. Neuroendocrinology 2000;72:333-340.

46 Desai M, Gayle D, Babu J, Ross MG: Programmed obesity in intrauterine growth restricted newborns: Modulation by newborn nutrition. Am J Physiol Regul Integr Comp Physiol 2005;288:R91-R96.

47 Bouret SG, Draper SJ, Simerly RB: Trophic action of leptin on hypothalamic neurons that regulate feeding. Science 2004;304:108-110

48 Cortelazzi D, Cappiello V, Morpurgo PS, Ronzoni S, Nobile De Santis MS, Cetin I, BeckPeccoz P, Spada A: Circulating levels of ghrelin in human fetuses. Eur J Endocrinol 2003;149: 111-116.

49 Makino Y, Hosoda H, Shibata K, Makino I, Kojima M, Kangawa K, Kawarabayashi T: Alteration of plasma ghrelin levels associated with the blood pressure in pregnancy. Hypertension 2002;39:781-784.
50 Bellone S, Rapa A, Vivenza D, Vercellotti A, Petri A, Radetti G, Bellone J, Broglio F, Ghigo E, Bona G: Circulating ghrelin levels in the newborn are positively associated with gestational age. Clin Endocrinol (Oxf) 2004;60: 613-617.

51 Chanoine JP, Yeung LP, Wong AC: Umbilical cord ghrelin concentrations in asian and Caucasian neonates. Horm Res 2003;60:116120.

-52 Farquhar J, Heiman M, Wong AC, Wach R, Chessex P, Chanoine JP: Elevated umbilical cord ghrelin concentrations in small for gestational age neonates. J Clin Endocrinol Metab 2003;88:4324-4327.

53 Kitamura S, Yokota I, Hosoda H, Kotani Y, Matsuda J, Naito E, Ito M, Kangawa K, Kuroda Y: Ghrelin concentration in cord and neonatal blood: Relation to fetal growth and energy balance. J Clin Endocrinol Metab 2003; 88:5473-5477.

54 Onal EE, Cinaz P, Atalay Y, Turkyilmaz C, Bideci A, Akturk A, Okumus N, Unal S, Koc E, Ergenekon E: Umbilical cord ghrelin concentrations in small- and appropriate-for-gestational age newborn infants: Relationship to anthropometric markers. J Endocrinol 2004; 180:267-271.

55 Volante M, Allia E, Fulcheri E, Cassoni P, Ghigo E, Muccioli G, Papotti M: Ghrelin in fetal thyroid and follicular tumors and cell lines: Expression and effects on tumor growth. Am J Pathol 2003;162:645-654.

56 Volante M, Fulcheri E, Allia E, Cerrato M, Pucci A, Papotti M: Ghrelin expression in fetal, infant, and adult human lung. J Histochem Cytochem 2002;50:1013-1021.

57 James RJ, Drewett RF, Cheetham TD: Low cord ghrelin levels in term infants are associated with slow weight gain over the first 3 months of life. J Clin Endocrinol Metab 2004; 89:3847-3850.

- 58 Iniguez G, Ong K, Pena V, Avila A, Dunger D, Mericq V: Fasting and post-glucose ghrelin levels in SGA infants: Relationships with size and weight gain at one year of age. J Clin Endocrinol Metab 2002;87:5830-5833.

59 Shimon I, Yan X, Melmed S: Human fetal pituitary expresses functional growth hormonereleasing peptide receptors. J Clin Endocrinol Metab 1998;83:174-178.

60 Soriano-Guillen L, Barrios V, Chowen JA, Sanchez I, Vila S, Quero J, Argente J: Ghrelin levels from fetal life through early adulthood: Relationship with endocrine and metabolic and anthropometric measures. J Pediatr 2004; 144:30-35.

61 Whatmore AJ, Hall CM, Jones J, Westwood M, Clayton PE: Ghrelin concentrations in healthy children and adolescents. Clin Endocrinol (Oxf) 2003;59:649-654.

62 Bunt JC, Salbe AD, Tschop MH, DelParigi A, Daychild P, Tataranni PA: Cross-sectional and prospective relationships of fasting plasma ghrelin concentrations with anthropometric measures in Pima Indian children. J Clin Endocrinol Metab 2003;88:3756-3761. 
63 Ghizzoni L, Mastorakos G, Vottero A, Ziveri M, Ilias I, Bernasconi S: Spontaneous growth hormone $(\mathrm{GH})$ secretion is not directly affected by ghrelin in either short normal prepubertal children or children with GH neurosecretory dysfunction. J Clin Endocrinol Metab 2004;89:5488-5495.

64 Cummings DE, Weigle DS, Frayo RS, Breen PA, Ma MK, Dellinger EP, Purnell JQ: Plasma ghrelin levels after diet-induced weight loss or gastric bypass surgery. N Engl J Med 2002;346: 1623-1630.

65 Cummings DE, Purnell JQ, Frayo RS, Schmidova K, Wisse BE, Weigle DS: A preprandial rise in plasma ghrelin levels suggests a role in meal initiation in humans. Diabetes 2001;50: 1714-1719.

-66 Cummings DE, Frayo RS, Marmonier C, Aubert R, Chapelot D: Plasma ghrelin levels and hunger scores in humans initiating meals voluntarily without time- and food-related cues. Am J Physiol Endocrinol Metab 2004;287: E297-E304.

67 Stock SL, Leichner P, Wong ACK, Ghatei MA, Kieffer TJ, Bloom SR, Chanoine JP: Ghrelin, PYY, GIP and hunger responses to a mixed meal in anorexic, obese and control female adolescents. J Clin Endocrinol Metab 2005 Jan 18 ; [Epub ahead of print].

68 Bellone S, Rapa A, Vivenza D, Castellino N, Petri A, Bellone J, Me E, Broglio F, Prodam F, Ghigo E, Bona G: Circulating ghrelin levels as function of gender, pubertal status and adiposity in childhood. J Endocrinol Invest 2002;25: RC13-15.

-69 Broglio F, Arvat E, Benso A, Gottero C, Muccioli G, Papotti M, van der Lely AJ, Deghenghi R, Ghigo E: Ghrelin, a natural GH secretagogue produced by the stomach, induces hyperglycemia and reduces insulin secretion in humans. J Clin Endocrinol Metab 2001;86: 5083-5086.

70 Nakagawa E, Nagaya N, Okumura H, Enomoto M, Oya H, Ono F, Hosoda H, Kojima M, Kangawa K: Hyperglycaemia suppresses the secretion of ghrelin, a novel growth-hormonereleasing peptide: Responses to the intravenous and oral administration of glucose. Clin Sci (Lond) 2002;103:325-328.

71 Saad MF, Bernaba B, Hwu CM, Jinagouda S, Fahmi S, Kogosov E, Boyadjian R: Insulin regulates plasma ghrelin concentration. J Clin Endocrinol Metab 2002;87:3997-4000.

72 Ikezaki A, Hosoda H, Ito K, Iwama S, Miura N, Matsuoka H, Kondo C, Kojima M, Kangawa K, Sugihara S: Fasting plasma ghrelin levels are negatively correlated with insulin resistance and PAI-1, but not with leptin, in obese children and adolescents. Diabetes 2002;51: 3408-3411.
73 Soriano-Guillen L, Barrios V, Campos-Barros A, Argente J: Ghrelin levels in obesity and anorexia nervosa: Effect of weight reduction or recuperation. J Pediatr 2004; 144:36-42.

74 Soriano-Guillen L, Barrios V, Lechuga-Sancho A, Chowen JA, Argente J: Response of circulating ghrelin levels to insulin therapy in children with newly diagnosed type 1 diabetes mellitus. Pediatr Res 2004;55:830-835.

75 Tschop M, Weyer C, Tataranni PA, Devanarayan V, Ravussin E, Heiman ML: Circulating ghrelin levels are decreased in human obesity. Diabetes 2001;50:707-709.

76 Misra M, Miller KK, Herzog DB, Ramaswamy K, Aggarwal A, Almazan C, Neubauer G, Breu J, Klibanski A: Growth hormone and ghrelin responses to an oral glucose load in adolescent girls with anorexia nervosa and controls. J Clin Endocrinol Metab 2004;89:1605-1612.

77 Soriano-Guillen L, Barrios V, Martos G, Chowen JA, Campos-Barros A, Argente J: Effect of oral glucose administration on ghrelin levels in obese children. Eur J Endocrinol 2004;151:119-121.

78 Mericq V, Cassorla F, Salazar T, Avila A, Iniguez G, Bowers CY, Merriam GR: Effects of eight months treatment with graded doses of a growth hormone $(\mathrm{GH})$-releasing peptide in GH-deficient children. J Clin Endocrinol Metab 1998;83:2355-2360.

79 Mericq V, Cassorla F, Garcia H, Avila A, Bowers CY, Merriam GR: Growth hormone $(\mathrm{GH})$ responses to $\mathrm{GH}$-releasing peptide and to $\mathrm{GH}$ releasing hormone in GH-deficient children. J Clin Endocrinol Metab 1995;80:1681-1684.

80 Pihoker C, Kearns GL, French D, Bowers CY: Pharmacokinetics and pharmacodynamics of growth hormone-releasing peptide-2: A phase I study in children. J Clin Endocrinol Metab 1998;83:1168-1172.

81 Racine MS, Symons KV, Foster CM, Barkan AL: Augmentation of growth hormone secretion after testosterone treatment in boys with constitutional delay of growth and adolescence: Evidence against an increase in hypothalamic secretion of growth hormone-releasing hormone. J Clin Endocrinol Metab 2004; 89:3326-3331.

$>82$ Butler MG: Prader-Willi syndrome: Current understanding of cause and diagnosis. Am J Med Genet 1990;35:319-332.

83 Schoeller DA, Levitsky LL, Bandini LG, Dietz WW, Walczak A: Energy expenditure and body composition in Prader-Willi syndrome. Metabolism 1988;37:115-120.

84 Cassidy SB: Prader-Willi syndrome. Curr Probl Pediatr 1984;14:1-55.

85 Holland AJ, Treasure J, Coskeran P, Dallow J: Characteristics of the eating disorder in Prader-Willi syndrome: implications for treatment. J Intellect Disabil Res 1995;39(Pt 5):373-381.
86 Thacker MJ, Hainline B, St Dennis-Feezle L, Johnson NB, Pescovitz OH: Growth failure in Prader-Willi syndrome is secondary to growth hormone deficiency. Horm Res 1998;49:216220.

87 Costeff H, Holm VA, Ruvalcaba R, Shaver J: Growth hormone secretion in Prader-Willi syndrome. Acta Paediatr Scand 1990;79: 1059-1062.

88 Tauber M, Conte Auriol F, Moulin P, Molinas C, Delagnes V, Salles JP: Hyperghrelinemia is a common feature of Prader-Willi syndrome and pituitary stalk interruption: A pathophysiological hypothesis. Horm Res 2004;62:4954.

89 Haqq AM, Farooqi IS, O'Rahilly S, Stadler DD, Rosenfeld RG, Pratt KL, LaFranchi SH, Purnell JQ: Serum ghrelin levels are inversely correlated with body mass index, age, and insulin concentrations in normal children and are markedly increased in Prader-Willi syndrome. J Clin Endocrinol Metab 2003;88:174178.

90 Paik KH, Jin DK, Song SY, Lee JE, Ko SH, Song SM, Kim JS, Oh YJ, Kim SW, Lee SH, Kim SH, Kwon EK, Choe YH: Correlation between fasting plasma ghrelin levels and age, body mass index (BMI), BMI percentiles, and 24-hour plasma ghrelin profiles in Prader-Willi syndrome. J Clin Endocrinol Metab 2004;89: 3885-3889.

91 Haqq AM, Stadler DD, Rosenfeld RG, Pratt KL, Weigle DS, Frayo RS, LaFranchi SH, Cummings DE, Purnell JQ: Circulating ghrelin levels are suppressed by meals and octreotide therapy in children with Prader-Willi syndrome. J Clin Endocrinol Metab 2003;88: 3573-3576.

92 Bizzarri C, Rigamonti AE, Giannone G, Berardinelli R, Cella SG, Cappa M, Muller EE: Maintenance of a normal meal-induced decrease in plasma ghrelin levels in children with Prader-Willi syndrome. Horm Metab Res 2004;36:164-169.

93 Tan TM, Vanderpump M, Khoo B, Patterson M, Ghatei MA, Goldstone AP: Somatostatin infusion lowers plasma ghrelin without reducing appetite in adults with Prader-Willi syndrome. J Clin Endocrinol Metab 2004;89: 4162-4165.

94 Haqq AM, Stadler DD, Jackson RH, Rosenfeld RG, Purnell JQ, LaFranchi SH: Effects of growth hormone on pulmonary function, sleep quality, behavior, cognition, growth velocity, body composition, and resting energy expenditure in Prader-Willi syndrome. J Clin Endocrinol Metab 2003;88:2206-2212. 